\title{
STUDIES OF GALLBLADDER FUNCTION. XV. CHOLESTEROL IN HUMAN LIVER BILE
}

\author{
By CECILIA RIEGEL, I. S. RAVDIN, AND HENRY ROSE \\ (From the Harrison Department of Surgical Research, Schools of Medicine, University of \\ Pennsylvania, and the Surgical Clinic of the Hospital of the \\ University of Pennsylvania, Philadelphia)
}

(Received for publication August 27, 1936)

The subject of bile drainage in the human has been very thoroughly reviewed by Fox (1) in 1928. Numerous papers have appeared, among which may be mentioned those of Walters, Green and Frederickson (2), Ravdin, Johnston, Riegel and Wright (3), and Elman and Graham (4), describing the changes occurring in hepatic bile obtained from patients with surgical drainage after the release of biliary obstruction in a varying number of cases. The data include, in addition to measurement of volume output, analyses for pigment, bile acids, chlorides and urea. Analyses for content of cholesterol, admittedly an important constituent of bile in its relation to stone formation, are few in number and usually absent in most of the papers cited. The present paper is a report of the daily variation in cholesterol concentration in hepatic bile of patients after some type of external biliary drainage.

\section{METHODS}

Thirty-two patients with external biliary drainage following operation are included in this study. The types of external drainage were as follows.

1. Cholecystostomy. Tube inserted into gallbladder through the fundus. The tip of the tube in some instances rested in the lumen of the gallbladder nearer the fundus than the cystic duct and in other instances the tip of the tube was pushed down into the cystic duct. Six cases of Type I (Figure 1) and 7 cases of Type II (Figure 2) are included.

2. Choledochostomy and cholecystectomyEight cases. The gallbladder was removed, and a $\mathrm{T}$ tube inserted into the common duct, the tip resting just below the junction of cystic duct and common duct (Type III, Figure 3).

3. Combination of choledochostomy and cholecystostomy-Seven cases (Type IV, Figure 4).

4. Cholecystectomy and cholecystodochostomy. In two instances the tube was inserted through the remaining stump of the cystic duct (Type V, Figure 5).

5. Cholecystodochostomy and choledochostomy -Two cases (Type VI, Figure 6). The bile obtained from Types II, III, V, VI and the common duct tube of IV, can be considered to be similar as in these cases the bile obtained does not enter the gallbladder. There is a possibility that in Type I and in the gallbladder tube of Type IV the bile may remain in the gallbladder for a time and be altered in its composition.

It was, of course, impossible in all instances to obtain the complete twenty-four hour output, as some bile passes down the common duct into the intestine in all cases where there is not complete

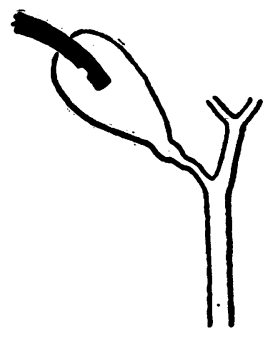

I

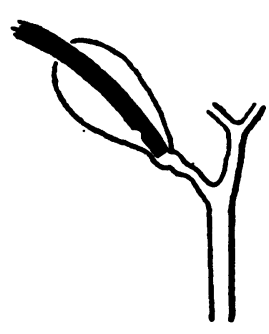

II

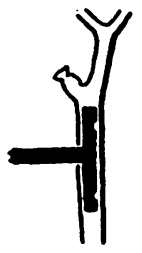

III

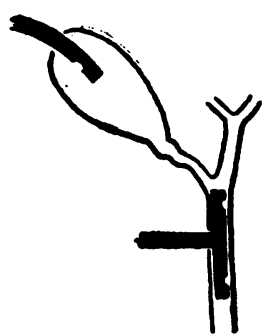

IV

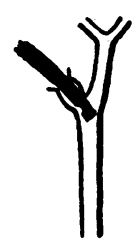

$\mathbf{Y}$

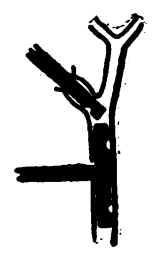

VI

Figs. 1 to 6. Methods of Intubating the Extra Hepatic Bile Passages 
TABLE I

Cholesterol concentration, fluid intake and amount of drainage

\begin{tabular}{|c|c|c|c|c|c|}
\hline Patient & $\begin{array}{c}\text { Days } \\
\text { after } \\
\text { opera- } \\
\text { tion }\end{array}$ & $\begin{array}{l}\text { Type of } \\
\text { drainage }\end{array}$ & Cholesterol & $\begin{array}{l}\text { Fluid } \\
\text { intake }\end{array}$ & Drainage \\
\hline H. L. & $\begin{array}{r}1 \\
2 \\
3 \\
4 \\
5 \\
6 \\
7 \\
8 \\
9 \\
10 \\
11 \\
12\end{array}$ & Gallbladder & $\begin{array}{c}\text { mgm. per cent } \\
34 \\
29 \\
75 \\
60 \\
70 \\
73 \\
51\end{array}$ & $\begin{array}{l}c c . \\
4760 \\
2060 \\
2240 \\
2200 \\
2300 \\
2550 \\
2320 \\
2750 \\
2230 \\
1920 \\
1840 \\
3250\end{array}$ & $\begin{array}{r}c c . \\
100 \\
30 \\
50 \\
50 \\
150 \\
75 \\
100 \\
100 \\
75 \\
50 \\
75\end{array}$ \\
\hline R. C. & $\begin{array}{r}2 \\
3 \\
4 \\
6 \\
7 \\
8 \\
9 \\
10 \\
11 \\
12 \\
13 \\
14\end{array}$ & Common duct & $\begin{array}{r}61 \\
57 \\
96 \\
86 \\
103 \\
67 \\
93 \\
61 \\
83 \\
86 \\
83 \\
90\end{array}$ & $\begin{array}{l}5210 \\
5630 \\
4910 \\
2640 \\
2810 \\
2810 \\
2110 \\
1540 \\
2140 \\
1830 \\
1470 \\
1600\end{array}$ & $\begin{array}{r}200 \\
250 \\
125 \\
10 \\
80 \\
30 \\
180 \\
180 \\
275 \\
550 \\
300\end{array}$ \\
\hline
\end{tabular}

obstruction of the lower end of that duct. Furthermore, for twenty-four to forty-eight hours after common duct intubation there may be some leakage of bile. In only two of the cases here reported was the common duct completely obstructed, and the bile drainage in these must closely approximate the complete daily twentyfour hour excretion. In all other instances only concentration of cholesterol could be determined. In a number of instances the first 2 or 3 specimens were contaminated with blood. Where this was the case the results were not considered in the following discussion.

In many instances the daily fluid intake of the patient was recorded, in order to determine its effect upon the concentration of cholesterol in the bile excreted. In some patients a portion of the collected bile was re-introduced through a Jutte tube, into the stomach. A record of this was kept and its effect on cholesterol concentration studied. Determinations of bile salt were made by the Gregory and Pascoe method (5). Cholesterol determinations were made as described by Riegel and Rose (6).

\section{RESULTS}

Daily analyses of cholesterol concentration in drainage bile show not only that there is considerable variation between different patients but -also that in the same patient the concentration may vary widely from day to day. Attempts to correlate these variations with alterations in other factors such as fluid intake, amount of external bile drainage, etc., were unsuccessful. The only correlation which appeared significant was with the amount of liver damage demonstrable at the operation.

A. Variations in concentration in the same patient. In Table I and Figures 7 and 8 are given the concentrations of cholesterol and fluid intake and amount of external bile drainage in two pa-

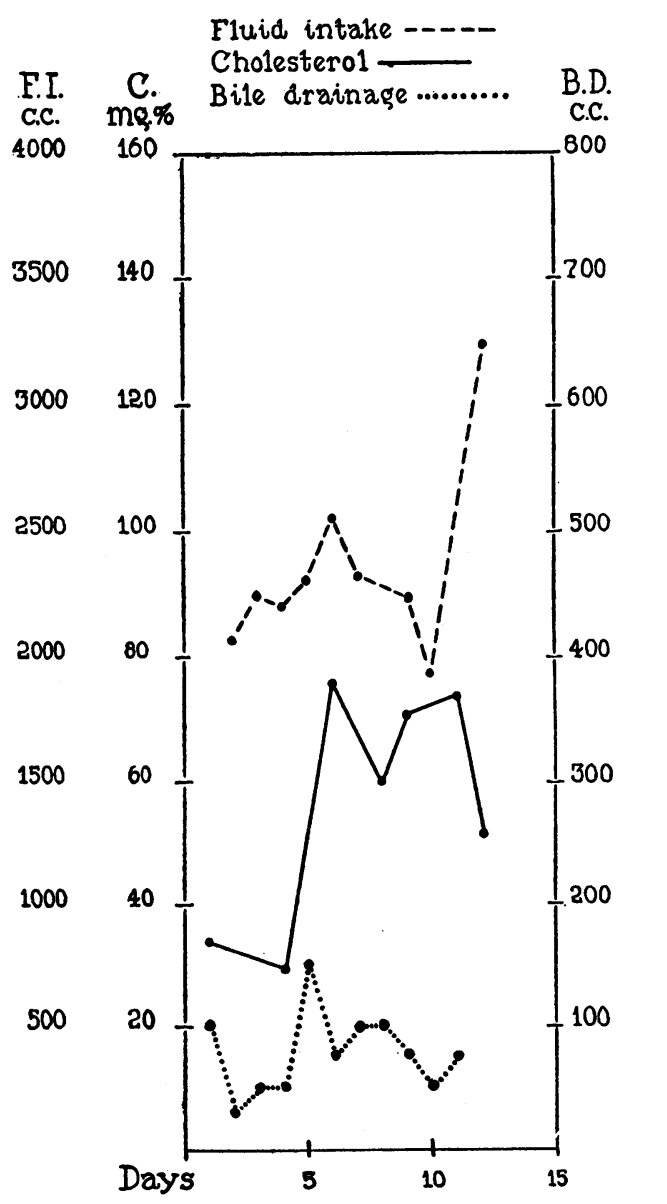

H.L:

Fig. 7. Fluid Intake, Cholesterol Concentration and Bile Drainage in Patient H. L. 
CHOLESTEROL IN HUMAN LIVER BILE

TABLE II

Variations in cholesterol concentration with extent of liver damage

\begin{tabular}{|c|c|c|c|c|c|c|c|c|c|c|c|c|c|c|}
\hline \multicolumn{15}{|c|}{ Daily concentration of cholesterol (mgm. per cent) } \\
\hline \multicolumn{4}{|c|}{ Slightly damaged } & \multicolumn{4}{|c|}{ Moderately damaged } & \multicolumn{7}{|c|}{ Badly damaged } \\
\hline $\begin{array}{c}\text { Patient } \\
\text { E. P. }\end{array}$ & $\begin{array}{l}\text { Patient } \\
\text { C. W. }\end{array}$ & $\begin{array}{c}\text { Patient } \\
\text { F. B. }\end{array}$ & $\begin{array}{l}\text { Patient } \\
\text { B. G. }\end{array}$ & $\begin{array}{l}\text { Patient } \\
\text { B. D. }\end{array}$ & $\begin{array}{l}\text { Patient } \\
\text { M. F. }\end{array}$ & $\begin{array}{l}\text { Patient } \\
\text { D. C. }\end{array}$ & $\begin{array}{l}\text { Patient } \\
\text { F. M. }\end{array}$ & $\begin{array}{l}\text { Patient } \\
\text { R. G. }\end{array}$ & $\begin{array}{l}\text { Patient } \\
\text { H. I. }\end{array}$ & $\begin{array}{l}\text { Patient } \\
\text { W. R. }\end{array}$ & $\begin{array}{l}\text { Patient } \\
\text { N. A. }\end{array}$ & $\begin{array}{l}\text { Patient } \\
\text { B. M. }\end{array}$ & $\begin{array}{l}\text { Patient } \\
\text { R.S. }\end{array}$ & $\begin{array}{l}\text { Patient } \\
\text { W. W. }\end{array}$ \\
\hline $\begin{array}{r}126 \\
58 \\
76 \\
101 \\
114 \\
132 \\
96 \\
82 \\
83\end{array}$ & $\begin{array}{r}133 \\
118 \\
99 \\
115 \\
83 \\
158 \\
172 \\
127 \\
70 \\
200 \\
225 \\
240 \\
211 \\
139 \\
152 \\
214 \\
82 \\
128\end{array}$ & $\begin{array}{r}61 \\
158 \\
153 \\
144 \\
123 \\
137 \\
21 \\
126 \\
98 \\
62\end{array}$ & $\begin{array}{r}8 \\
30 \\
19 \\
15 \\
21 \\
67 \\
85 \\
77 \\
90 \\
133 \\
71 \\
47 \\
154 \\
57\end{array}$ & $\begin{array}{r}40 \\
43 \\
133 \\
150 \\
106 \\
92 \\
84 \\
174 \\
154 \\
108 \\
90 \\
133 \\
198\end{array}$ & $\begin{array}{r}86 \\
17 \\
37 \\
87 \\
133 \\
112 \\
155 \\
136 \\
126 \\
146 \\
159 \\
154 \\
170 \\
152 \\
123 \\
76\end{array}$ & $\begin{array}{r}180 \\
61 \\
57 \\
96 \\
86 \\
103 \\
67 \\
93 \\
61 \\
83 \\
86 \\
83 \\
90 \\
169 \\
110 \\
123\end{array}$ & $\begin{array}{r}59 \\
47 \\
200 \\
108 \\
119 \\
218\end{array}$ & $\begin{array}{l}27 \\
35\end{array}$ & $\begin{array}{l}26 \\
12 \\
13 \\
19 \\
22 \\
23 \\
29 \\
34 \\
49 \\
53 \\
53 \\
47 \\
54 \\
48 \\
70 \\
65\end{array}$ & $\begin{array}{r}10 \\
14 \\
9 \\
12 \\
16 \\
16 \\
15 \\
6 \\
14 \\
9\end{array}$ & $\begin{array}{r}30 \\
13 \\
13 \\
14 \\
13 \\
9 \\
13 \\
11 \\
20 \\
11 \\
25 \\
9 \\
5 \\
14\end{array}$ & $\begin{array}{l}39 \\
41 \\
35 \\
47 \\
29 \\
30 \\
30 \\
30 \\
33 \\
39 \\
47 \\
62 \\
72 \\
48 \\
80 \\
63 \\
49 \\
47 \\
45 \\
51 \\
51 \\
58 \\
62 \\
42 \\
28\end{array}$ & $\begin{array}{l}67 \\
36 \\
32 \\
38 \\
29 \\
30 \\
31 \\
35 \\
35 \\
23 \\
50 \\
39 \\
36 \\
19 \\
14 \\
27\end{array}$ & $\begin{array}{l}38 \\
35 \\
26 \\
20 \\
11 \\
29 \\
23 \\
50 \\
35\end{array}$ \\
\hline
\end{tabular}

tients studied. In the first patient, cholesterol concentration varied from 29 to 75 milligrams per cent, and in the second, from 57 to 103. One might expect that with greater fluid intake the volume of the collected bile would be greater, and the concentration of the bile constituents lower. No such relationship was found in these patients.

There is considerable daily variation in the amount of bile drainage through the collecting tube, but no relationship between this and the cholesterol concentration could be demonstrated.

The daily variations in cholesterol concentration agree with the data reported by Elman and Taussig (7) in the two patients they studied, and the data obtained by McMaster (8) from the dog.

There is a suggestion of correlation between the condition of the liver and its ability to function, and the concentration of cholesterol. In most of the patients the samples of bile collected in the first two or three days after operation, before the liver had begun to recover from the effects of obstruction, were lower in cholesterol concentration than subsequent samples obtained at a time when hepatic function was improving.

$B$. Variations in concentration in different patients. When the patients were grouped according to extent of liver damage, as observed at operation, the seven patients known to have badly damaged livers had extremely low concentrations of cholesterol in the bile, while in the moderately or. slightly damaged groups the concentrations on the whole were considerably higher. In Table II are given the data from the seven patients with a badly damaged liver, together with the data from four patients with a moderately damaged liver and four patients with a slightly damaged liver.

Table III shows that refeeding bile to the patients has little effect on cholesterol concentration, although Whipple (9) has shown that feeding bile salts to dogs increases cholesterol output.

One must take into account the fact that the bile which was refed, the patient's own bile, was not normal and almost certainly contained at least 


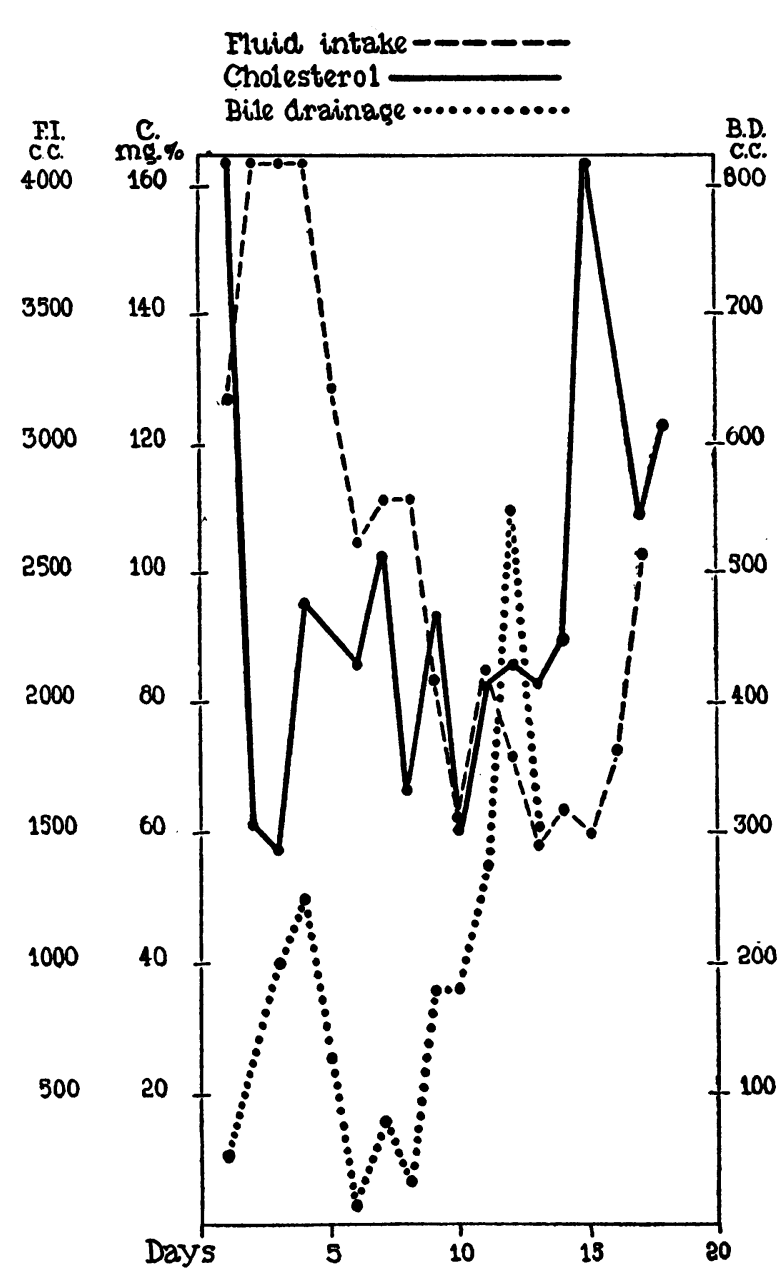

R.C.

Fig. 8. Fluid intake, Cholesterol Concentration and Bile Drainage in Patient R. C.

for a time, little or no bile salt. In fact, at all times during these experiments it contained considerably less than the normal amount of bile salt (3). The feeding of a bile high in bile salt concentration would perhaps have caused an increase in concentration of cholesterol, such as Whipple (9) reported in dogs.

This viewpoint is strengthened by the comparison of the concentrations of bile salt and cholesterol (Figure 9). In general, the concentrations of bile salt and cholesterol in the same patient varied directly with each other, the patients with the higher cholesterol concentrations having higher bile salt concentrations. There is, however, no correlation between the absolute amounts
TABLE III

\begin{tabular}{|c|c|c|c|c|}
\hline Patient & Liver & $\begin{array}{l}\text { Days } \\
\text { after } \\
\text { oper- } \\
\text { ation }\end{array}$ & $\begin{array}{c}\text { Choles- } \\
\text { terol }\end{array}$ & Bile refed \\
\hline B. D. & Moderate damage & $\begin{array}{r}5 \\
8 \\
9 \\
11 \\
12 \\
13 \\
14 \\
15 \\
16 \\
17 \\
18 \\
19 \\
20 \\
21 \\
22 \\
23 \\
26 \\
28 \\
29\end{array}$ & $\begin{array}{r}43 \\
133 \\
150 \\
106 \\
92 \\
\\
\\
94 \\
174 \\
154 \\
108 \\
90 \\
133 \\
198\end{array}$ & $\begin{array}{r}c c . \\
0 \\
0 \\
0 \\
100 \\
50 \\
200 \\
200 \\
200 \\
200 \\
200 \\
200 \\
200 \\
200 \\
200 \\
200 \\
200 \\
0 \\
0 \\
0\end{array}$ \\
\hline \multirow{2}{*}{ W. R. } & \multirow{2}{*}{ Badly damaged } & \multirow[b]{2}{*}{$\begin{array}{r}4 \\
5 \\
6 \\
10 \\
12 \\
15 \\
18 \\
21 \\
26 \\
29\end{array}$} & \multirow[b]{2}{*}{$\begin{array}{l}38 \\
35 \\
26 \\
20 \\
11 \\
29 \\
23 \\
50 \\
35\end{array}$} & $\begin{array}{l}\text { Feeding continued } \\
\text { for three weeks }\end{array}$ \\
\hline & & & & $\begin{array}{l}850 \\
800 \\
500 \\
500 \\
500 \\
500 \\
500 \\
500 \\
500 \\
500\end{array}$ \\
\hline
\end{tabular}

TABLE IV

Twenty-four hour output of cholesterol in total liver bile

\begin{tabular}{|c|c|c|c|}
\hline $\begin{array}{l}\text { Days after } \\
\text { operation }\end{array}$ & Drainage & $\begin{array}{l}\text { Cholesterol } \\
\text { concentration }\end{array}$ & $\begin{array}{l}\text { Cholesterol per } \\
24 \text { hours }\end{array}$ \\
\hline & $c c$. & mgm. per cent & mgm. \\
\hline \multicolumn{4}{|c|}{ PATIENT $\mathbf{W}$} \\
\hline $\begin{array}{r}4 \\
6 \\
10 \\
12 \\
15 \\
18 \\
21 \\
26\end{array}$ & $\begin{array}{r}400 \\
900 \\
1100 \\
1600 \\
2700 \\
1500 \\
3500 \\
3000\end{array}$ & $\begin{array}{l}38 \\
35 \\
26 \\
20 \\
11 \\
29 \\
23 \\
50\end{array}$ & $\begin{array}{r}152 \\
315 \\
286 \\
320 \\
297 \\
435 \\
805 \\
1500\end{array}$ \\
\hline \multicolumn{4}{|c|}{ PATIENT M } \\
\hline $\begin{array}{r}5 \\
7 \\
9 \\
11 \\
13\end{array}$ & $\begin{array}{l}350 \\
350 \\
450 \\
300 \\
500\end{array}$ & $\begin{array}{l}39 \\
41 \\
35 \\
47 \\
29\end{array}$ & $\begin{array}{l}137 \\
144 \\
158 \\
141 \\
145\end{array}$ \\
\hline
\end{tabular}




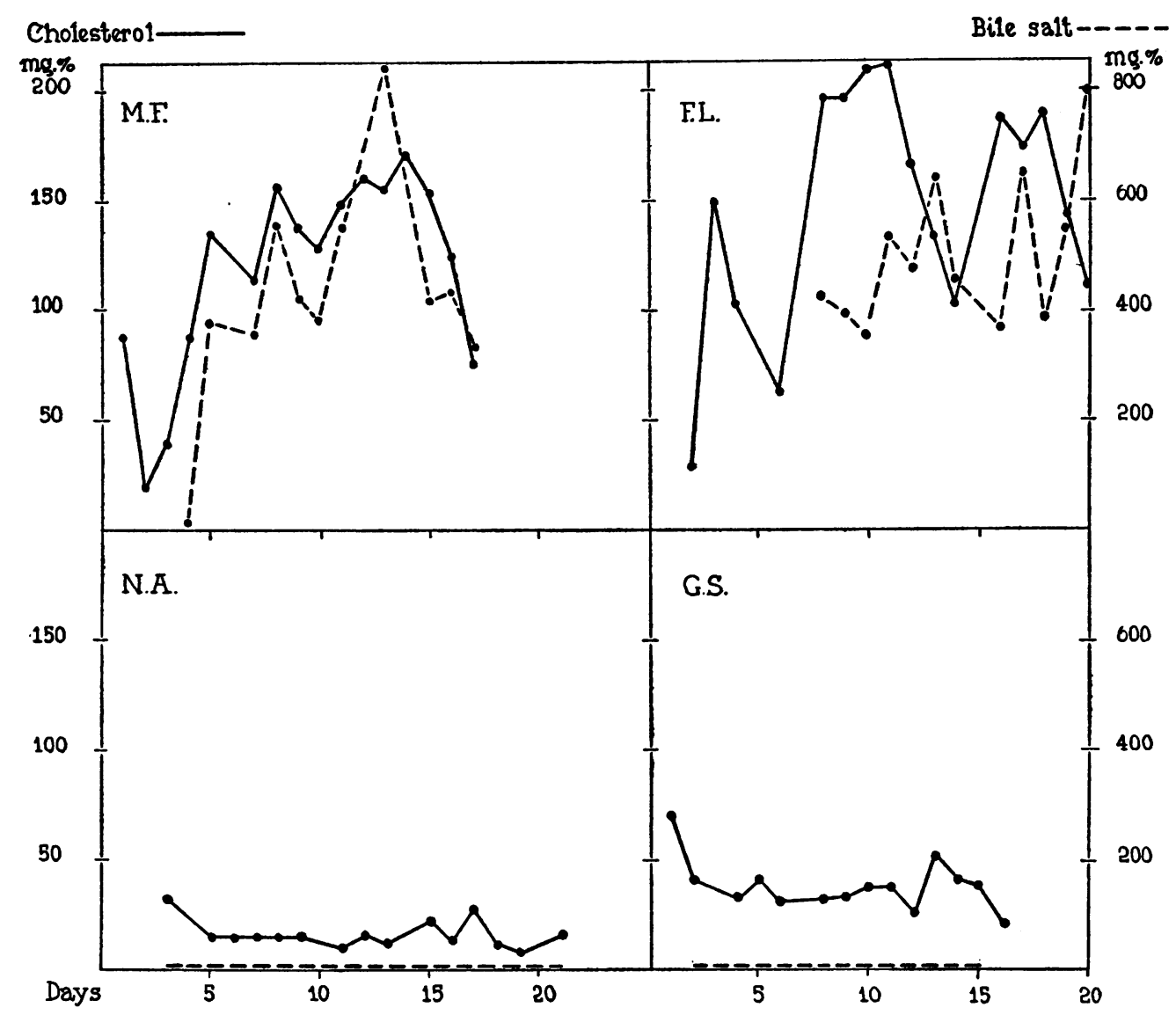

Fig. 9. Comparison of Concentrations of Cholesterol and Bile Salt in Four Patients

of bile salt and cholesterol; that is, one cannot predict from a given concentration of cholesterol what the level of bile salt will be, or vice versa.

Twenty-four hour bile excretion. In two patients whom we studied there was complete obstruction of the common duct due to a lesion in the head of the pancreas, and the bile collected represents the complete twenty-four hour output of the liver. Table IV shows the concentrations and total amounts of cholesterol in the bile from these two patients.

\section{SUMMARY}

The data reported in this paper were obtained from patients who had some disease of the biliary tract with or without complete obstruction of the common bile duct prior to operation. Even in those patients whose total hepatic excretion of bile was collected the amount varied considerably from day to day. The amount of bile collected by external drainage was not directly related to the fluid intake of the patient.

Cholesterol concentration as well as total output of cholesterol in the liver bile, where this could be determined, varied in the same patient and in different patients, from day to day. In general the more severely damaged the liver, the lower was the cholesterol concentration in the liver bile, and the lower was the concentration of bile salt.

The feeding of the patients' own bile, while without doubt of value as far as the patients' clinical improvement was concerned, did not result in an elevation of the cholesterol concentration in the liver bile.

The study of the cholesterol-bile salt concentrations should prove of real value in determining the functional state of the liver when common duct drainage has been instituted. 


\section{BIBLIOGRAPHY}

1. Fox, F. W., The composition of human bile and its bearing upon sterol metabolism. Quart. J. Med., 1927-28, 21, 107.

2. Walters, W., Greene, C. H., and Frederickson, C. H., The composition of the bile following the relief of biliary obstruction. Ann. Surg., 1930, 91, 686.

3. Ravdin, I. S., Johnston, C. G., Riegel, C., and Wright, S. L., A study of human liver bile after release of common duct obstruction. J. Clin. Invest., 1933, 12, 659.

4. Elman, R., and Graham, E. A., The pathogenesis of the "strawberry" gallbladder (cholesterosis of the gallbladder). Arch. Surg., 1932, 24, 14.

5. Gregory, R., and Pascoe, T. A., The quantitative de- termination of bile acids by means of a new color reaction and monochromatic light. J. Biol. Chem., 1929, 83, 35.

6. Riegel, C., and Rose, H. J., Determination of free and combined cholesterol in bile. J. Biol. Chem., 1936, 113, 117.

7. Elman, R., and Taussig, J. B., The cholesterol function of the gall bladder. J. Exper. Med., 1931, 54, 775.

8. McMaster, P. D., Studies on the total bile. VI. The influence of diet upon the output of cholesterol in the bile. J. Exper. Med., 1924, 40, 25.

9. Whipple, G. H., The origin and significance of the constituents of the bile. Physiol. Rev., 1922, 2, 440. 